\title{
The Rebirth of Sustainable Post-Pandemic Tourism. Case Study: Romania
}

\author{
Alexandru Dobrescu' ${ }^{1}$, iD, Mirela Mazilu ${ }^{1}$ \\ ${ }^{1}$ University of Craiova, Faculty of Sciences, Department of Geography, 13 A. I. Cuza Street 200585, Craiova, \\ Dolj County, Romania \\ dobrescu.sorin.alexandru@gmail.com (A.D.); mirelamazilu2004@yahoo.com (M.M.)
}

Received: 27 October 2020; Revised: 4 December 2020; Accepted: 7 December 2020; Published online: 15 December 2020

\begin{abstract}
Traveling is definitely a way of life for many of us. However, the year of 2020 is the year of great changes, the tourism sector collapsing with the appearance of the COVID-19 pandemic. It is still too early to see the long-term effects caused by this SARS-CoV-2 virus, especially since this paper aims to analyze the situation of the tourism sector in the first half of 2020. Thus, the review of the impediments encountered in international tourism and of some possible ways of tourist recovery for the postpandemic period represented aspects of great interest for the author. Romania being a CarpathianDanubian-Pontic country, has a natural tourist potential that can attract tourists and generate profits that can propel the Romanian tourism sector among the national economic sectors that contribute greatly to the formation of national GDP. It is interesting how this paper presents the situation of a country in which the tourist potential is not properly valued and in the difficult context of the present COVID-19 pandemic, can by implementing key strategies aimed at practicing sustainable tourism, gain "ground" in the international tourism, respecting by the way, at the same time as practicing tourism, the health safety measures that currently represent a daily priority.
\end{abstract}

Key words: sustainable development, COVID-19 pandemic, Romania, tourism, post-pandemic tourism, politics and strategies, sustainable tourism

Citation: Dobrescu, A., \& Mazilu, M. (2020). The Rebirth of Sustainable Post-Pandemic Tourism. Case Study: Romania. Central European Journal of Geography and Sustainable Development, 2(2), 52-64. https://doi.org/10.47246/CEJGSD.2020.2.2.5

https://doi.org/10.47246/CEJGSD.2020.2.2.5

\section{| Full text $\mid$}

